\title{
PRIMARY RAT SERTOLI AND INTERSTITIAL CELLS EXHIBIT A DIFFERENTIAL RESPONSE TO CADMIUM'
}

\author{
STEPHEN R. CLOUGH, ${ }^{a}$ MICHAEL J. WELSH, ${ }^{\mathrm{c}}$ ANITA H. PAYNE, de \\ CARL D. BROWN, ${ }^{b}$ AND MICHAEL J. BRABECb
}

\author{
Eastern Michigan University, Department of Chemistry, ${ }^{b}$ The University of Michigan \\ Department of Environmental and Industrial Health, Toxicology Programa \\ Department of Anatomy and Cell Biology, ${ }^{\mathrm{c}}$ and \\ Department of Obstetrics and Gynecology ${ }^{d}$ and Biological Chemistrye
}

\begin{abstract}
Two cell types central to the support of spermatogenesis, the Sertoli cell and the interstitial (Leydig) cell, were isolated from the same cohort of young male rats and challenged with cadmium chloride to compare their susceptibility to the metal. Both cell types were cultured under similar conditions, and similar biochemical endpoints were chosen to minimize experimental variability. These endpoints include the uptake of ${ }^{109} \mathrm{Cd}$, reduction of the vital tetrazolium dye MTT, incorporation of ${ }^{3} \mathrm{H}$-leucine, change in heat-stable cadmium binding capacity, and production of lactate. Using these parameters, it was observed that the Sertoli cell cultures were adversely affected in a dose-and time-dependent manner, while the interstitial cell cultures, treated with identical concentrations of $\mathrm{CdCl}_{2}$, were less affected. The 72-hr LC $C_{50}$ 's for Sertoli cells and interstitial cells were 4.1 and $19.6 \mu \mathrm{M} \mathrm{CdCl}$, respectively. Thus, different cell populations within the same tissue may differ markedly in susceptibility to a toxicant. These in vitro data suggest that the Sertoli cell, in relation to the interstitium, is particularly sensitive to cadmium. Because the Sertoli cell provides functional support for the seminiferous epithelium, the differential sensitivity of this cell type may, in part, explain cadmium-induced testicular dysfunction, particularly at doses that leave the vascular epithelium intact.
\end{abstract}

\footnotetext{
.1. All correspondence should be sent to: Michael J. Brabec, Department of Chemistry, Mark-Jefferson Building, Eastern Michigan University, Ypsilanti, MI 48197; 313-487-2039.

2. Key words: cadmium, Sertoli cell, interstitial cell, testis, rat.

3. Abbreviations: CBF, cadmium-binding factor; DMEM, Dulbecco's modified Eagle's medium; FSH, follicle stimulating hormone; ICC, interstitial cell culture; IGF-I, insulin-like growth factor-I; LC(50), 50\% lethal concentration; MTT, 3-(4,5-dimethylthiazol-2-yl); SCC, Sertoli cell culture.

4. This work was supported by NIEHS ESO4141 and NIH HD-08358 (AHP).

5. Preliminary results of some of this work were reported at the 26th Annual Meeting of the Society of Toxicology (1987), Washington, DC.
} 


\section{INTRODUCTION}

Experimentally, cadmium is the most potent male reproductive toxicant known. A single injection of the metal salt $(>10 \mu \mathrm{mol} / \mathrm{kg})$ will cause complete "necrosis" of the testis in most laboratory mammals, despite the fact that the testis accrues, in relation to other organs, the smallest percentage of the dose (Parizek and Zahor, 1956; Gunn et al., 1968a). It has been suggested that the histopathological changes seen (and subsequent infertility) are secondary to the destruction of the testicular vasculature by cadmium (for Review: see Lee, 1983; Parizek, 1983; Singhal et al., 1985).

However, acute cadmium administration to rats below $4 \mu \mathrm{mol} / \mathrm{kg}$ will also produce significant reproductive effects (Meek, 1959; Kar and Das, 1960; Lee and Dixon, 1973) in the absence of any adverse effects to the testicular vasculature (Gunn et al., 1966). Recent studies have shown that changes in serum FSH or testosterone concentration may represent the most sensitive endpoints after acute cadmium administration in rats (Laskey et al., 1984; Laskey et al., 1986). Thus, either the Sertoli or the Leydig cell may be the initial testicular target of cadmium.

Although many studies have been performed with regard to the effect of cadmium on cells isolated from other tissues, little information exists on the effect of cadmium on testicular cells in vitro. Espevik et al. (1982) investigated the effects, as well as the prevention, of cadmium cytotoxicity in primary cultures of rat $(20$ day) Sertoli cells. They reported a $72 \mathrm{hr} \mathrm{LC}{ }_{50}$ of $3.6 \mu \mathrm{M} \mathrm{CdCl}_{2}$ and found that pretreatment with selenium, zinc, or cadmium had a prophylactic effect toward subsequent cadmium exposure, whereas FSH, estradiol, or testosterone did not. Waalkes and Poirer (1985) observed that the uptake of cadmium by freshly isolated adult rat interstitial cell preparations is multiphasic, with the secondary phase being saturable, energy dependent, and inhibited by zinc. Cell viability was not reduced by cadmium concentrations up to $100 \mu \mathrm{M}$ and the efflux of metal ion from these cells at a fairly significant rate.

This study examined differences in susceptibility between Sertoli and interstitial cells to low cadmium concentrations in vitro. These two cell types were chosen because they play central roles in the support and control of spermatogenesis, are potential targets for cadmium in vivo, and are amendable to culture in vitro. A consanguinous preparation of Sertoli cells and purified interstitial cells was utilized. This design allowed the comparison of common metabolic endpoints and minimized experimental variability. Morphology, respiratory activity, total protein synthesis, appearance of a heat-stable cadmium binding factor, and lactate synthesis were compared between the two cultures. These observations suggest that the Sertoli cell is much more sensitive to the effects of cadmium than the interstitial cell in vitro. The results, along with those of others (Boscolo et al., 1985; Chung and 
Maines, 1987), support the premise that the reduction of male fertility could be the result of an early, direct toxic effect of cadmium on the Sertoli cell.

\section{MATERIALS AND METHODS}

Media and Reagents. All reagents and medium components were obtained from Sigma Chemical Co., St. Louis, MO. Cadmium chloride (Baker Chemical Company, Phillipsburg, N.J.) was recrystallized $2 \mathrm{X}$, filtered, and desiccated. Stock $\mathrm{CdCl}_{2}$ solutions were prepared in $0.9 \%$ saline and sterile filtered; these solutions were analyzed against a commercial cadmium standard using a Perkin-Elmer 403 atomic absorption spectrophotometer. ${ }^{109} \mathrm{Cd}$ and ${ }^{3} \mathrm{H}$-leucine were obtained from New England Nuclear, Boston, MA. The activity per ml of medium was 0.2 and 1.0 $\mu \mathrm{Ci}$, respectively. Metrizamide was purchased from Accurate Chem. \& Scientific Corp., Hicksville, N.Y. Nitex mesh was purchased from Wilflife Biological Supply, Saginaw, MI. Anti-desmin monoclonal antibody and mouse anti-IgG-FITC were obtained from Boehringer-Mannheim, Indianapolis, IN.

Animals: Male Sprague-Dawley CD-1 rats were purchased from Charles River Breeding Laboratories, Inc., Wilmington, MA. The age at arrival was 19-21 days. The rats were weaned, caged with bedding, and held in an environmentally controlled room until 27-30 days of age. At this time they were killed by cervical dislocation.

Cell Preparation. Culture medium (DME/F12) used throughout this study was a serum-free medium based on a 50:50 mixture of Ham's DMEM/F12 formula with insulin $(10 \mathrm{mg} / \mathrm{l})$, epidermal growth factor $(25 \mu \mathrm{g} / \mathrm{l})$, and transferrin $(5 \mathrm{mg} /$ 1) (Mather, 1980). Lactate was omitted from the formulation. Testes from 6-10 rats were aseptically removed and placed in ice cold calcium, magnesium-free, phosphate buffered saline containing $97.6 \mathrm{mM} \mathrm{NaCl}, 25 \mathrm{mM} \mathrm{KCl}, 3.7 \mathrm{mM} \mathrm{Na}_{2} \mathrm{PO}_{4}$, $8.3 \mathrm{mM}$ glucose, $50 \mathrm{U} / \mathrm{ml}$ penicillin, $50 \mu \mathrm{g} / \mathrm{ml}$ streptomycin sulfate, and 0.008 $\mathrm{mM}$ phenol red in deionized, distilled water, $\mathrm{pH}$ 7.4. Testes were then decapsulated and weighed. The method of Chase and Payne (1983) was then followed for the isolation of partially purified Leydig cells, except for the following modifications: 1) all medium used was DME/F12;2) a linear $11-23 \%$ gradient was prepared by layering, from bottom to top, three $5 \mathrm{ml}$ volumes of media containing 23, 17 , and $11 \%$ Metrizamide into a $38 \mathrm{ml}$ roundbottom polycarbonate centrifuge tube and stored for $48 \mathrm{hr}$ at $4^{\circ}$. Following isolation, the partially purified interstitial cells were counted in a hemocytometer and plated at a density of $0.8-1.2 \times 10^{6}$ cells $/ 35 \mathrm{~mm}$ plate into a total volume of $2.5 \mathrm{ml}$ medium. The cells were allowed to attach $\left(2 \mathrm{hr}\right.$ at $\left.32^{\circ}\right)$ and the medium was then replaced with $2 \mathrm{ml}$ of fresh medium and the plates incubated at $32^{\circ}$ in a $5 \% \mathrm{CO}_{2}-95 \%$ air atmosphere. The average yield of this preparation was $1.7 \times 10^{6}$ cells/testis. Staining for 3-betahydroxysteroid dehydrogenase activity with nitro blue tetrazolium (NBT) revealed an average Leydig cell purity of $42 \%$. Indirect immunofluorescence using antidesmin monoclonal antibody conjugated with mouse anti-IgG-FITC (supplier 
procedure) revealed an average peritubular cell composition of $11 \%$. The tubules remaining after enzymatic digestion (above), were transferred to 20 micron Nitex mesh and blotted from below the gauze. The procedure for isolation of Sertoli cells was then followed according to the method of Welsh and Wiebe (1975) as modified by Beattie et al. (1984), with the following modifications: 1) the incubation temperature during the first digestion was $34^{\circ} ; 2$ ) the incubation time was 35 $40 \mathrm{~min}$; 3) the pancreatin digestion period was $15 \mathrm{~min}$. After isolation, 10-12 $\mu \mathrm{l}$ $\left(0.8-1.2 \times 10^{6}\right.$ Sertoli cells) of packed cell pellet was plated per $35 \mathrm{~mm}$ petri dish. Sertoli cells were plated into a total volume of $2 \mathrm{ml}$ medium, and allowed to attach to culture dishes at $37^{\circ}$ for $24 \mathrm{hr}$ under the same gas composition as above.

Culture Conditions. The day of isolation was designated Day 0. On day 1 (24 hours post-isolation), the medium was changed and both cell types were placed into the same incubation unit $\left(32^{\circ}\right)$. On day 3 , the Sertoli cells were treated for 2 min with $20 \mathrm{mM}$ Tris/ $\mathrm{HCl}, \mathrm{pH} 7.4$ to eliminate germ cells as described by Galdieri et al. (1981). The medium was then changed for both cell populations. Media containing cadmium was prepared fresh before each experiment. All experiments were initiated on day 4 , and each figure shown, unless noted otherwise, represents the mean $(+/-$ range) of two experiments. Cultures remained viable over a four day incubation period, as indicated by no significant change in their ability to reduce the vital dye MTT (data not shown).

Reduction of MTT. Cell preparations on Day 0 were routinely examined and counted in $0.04 \%$ trypan blue and consistently exceeded $95 \%$ viability as measured by dye exclusion. Respiratory activity of cadmium exposed cells (Day 4-7) was assessed by the ability of live cells to reduce the tetrazolium dye MTT as described by Mosmann (1983). Cells were plated into 24 well plates at the same density as above. After treatment, $100 \mu \mathrm{l}$ of dye $(4 \mathrm{mg} / \mathrm{ml}$ in Dulbecco's phosphate buffered saline) was added to each well and incubated for $2 \mathrm{hr}$ at $32^{\circ}$. Following incubation,

each plate was rotated at $100 \mathrm{cycles} / \mathrm{min}$ for $5 \mathrm{~min}$ to dislodge any unattached cells. The medium was aspirated, and $1 \mathrm{ml}$ of a 50:50 Dulbecco's PBS:acid isopropanol solution added to each well. The optical density of each well was read at $560 \mathrm{~nm}$, and the amount of formazan produced calculated by using a molar extinction coefficient of 51,000 (Pearse, 1960).

Lactate Determinations. Lactate concentrations in media (frozen aliquots) were determined (in duplicate) enzymatically by the method of Hohurst (1965) as modified

by Brabec et al. (1984). PROTEIN SYNTHESIS. Protein synthesis was measured by the incorporation of ${ }^{3} \mathrm{H}$-leucine into TCA insoluble material by a modification of the method of Tash et al. (1981). Briefly, after cadmium exposure, cells were incubated in medium containing $2 \mu \mathrm{Ci}^{3} \mathrm{H}$-leucine. After a 3 hour incubation, the plates were washed with complete medium, Dulbecco's PBS and finally solubilized 
in $1.1 \mathrm{ml} 0.5 \mathrm{~N} \mathrm{NaOH} / 1 \%$ sodium deoxycholate. Following transfer to disposable test tubes, a $100 \mu \mathrm{l}$ aliquot was taken for protein determination and the remainder acidified with $3 \mathrm{ml}$ of ice cold $40 \%$ TCA. After 24 hours at $4^{\circ}$, the suspensions were rinsed onto a glass fiber filter (Whatman GF/ A, $2.4 \mathrm{~cm}$ ) in a BioRad vacuum manifold, washed with $3 \mathrm{ml} \mathrm{10 \%}$ TCA with $40 \times$ cold leucine, 95\% EtOH, 50:50 95\% EtOH:ethyl ether, and finally 100\% ethyl ether. The filter paper was placed in a plastic minivial with $6 \mathrm{ml}$ ACS scintillation cocktail (Amersham), and the radioactivity in each sample determined in a Delta 300 liquid scintillation spectrometer.

Induction of Heat-Stable Cadmium Binding Factor (CBF). Following cadmium exposure, each plate was rinsed once with fresh medium and Dulbecco's PBS. One $\mathrm{ml}$ of $20 \mathrm{mM}$ Tris/ $\mathrm{HCl}, \mathrm{pH} 7.4$ was then added and the plates were frozen and thawed twice. The contents of each plate was subsequently sonicated for 1 min, transferred to glass test tubes, and assayed directly for 'cadmium binding capacity' by the method of Onsaka et al. (1978) as modified by Eaton and Toal (1982).

Cadmium Uptake and Efflux. To each culture dish, $1 \mathrm{ml}$ of medium containing $1 \mu \mathrm{M} \mathrm{CdCl}_{2}\left(0.2 \mu \mathrm{Ci}{ }^{109} \mathrm{Cd} / \mathrm{ml}\right)$ was added and the cultures were incubated as above. Uptake and efflux of the metal was then measured according to the procedure of Failla and Cousins (1978).

Protein Determination. Protein determinations were made by the method of Lowry (1951) as modified by Peterson (1977). Sertoli cell and interstitial cell cultures were plated at an equal cell density $\left(1 \times 10^{5}\right.$ cells $\left./ \mathrm{cm}^{2}\right)$. On the average $(\mathrm{n}=30$ plates per experiment), Sertoli cell cultures had 1.6 times the protein content of the interstitial cell cultures.

Data Analyses. Means were compared by two-way analysis of variance (ANOVA using SPSS) and, for pair-wise comparisons, Duncan's multiple range (Gad and Weil, 1982).

\section{RESULTS}

Morphology. Microscopic observations of control and cadmium-treated Sertoli cell cultures (SCC) showed dose-related responses, primarily granular cytoplasm, pyknosis, cell rounding and detachment. Observations of interstitial cell cultures (ICC) treated at identical concentrations $\left(0-4.5 \mu \mathrm{M} \mathrm{CdCl}_{2}\right)$ revealed no apparent morphological changes. Similar responses in ICC could only be seen at concentrations exceeding $8 \mu \mathrm{M} \mathrm{CdCl}_{2}$.

Cadmium Uptake. At a cadmium concentration of $1 \mu \mathrm{M}$, the rate of transport of the metal were similar for both cell types (Figure 1). The accumulation of cadmium, 


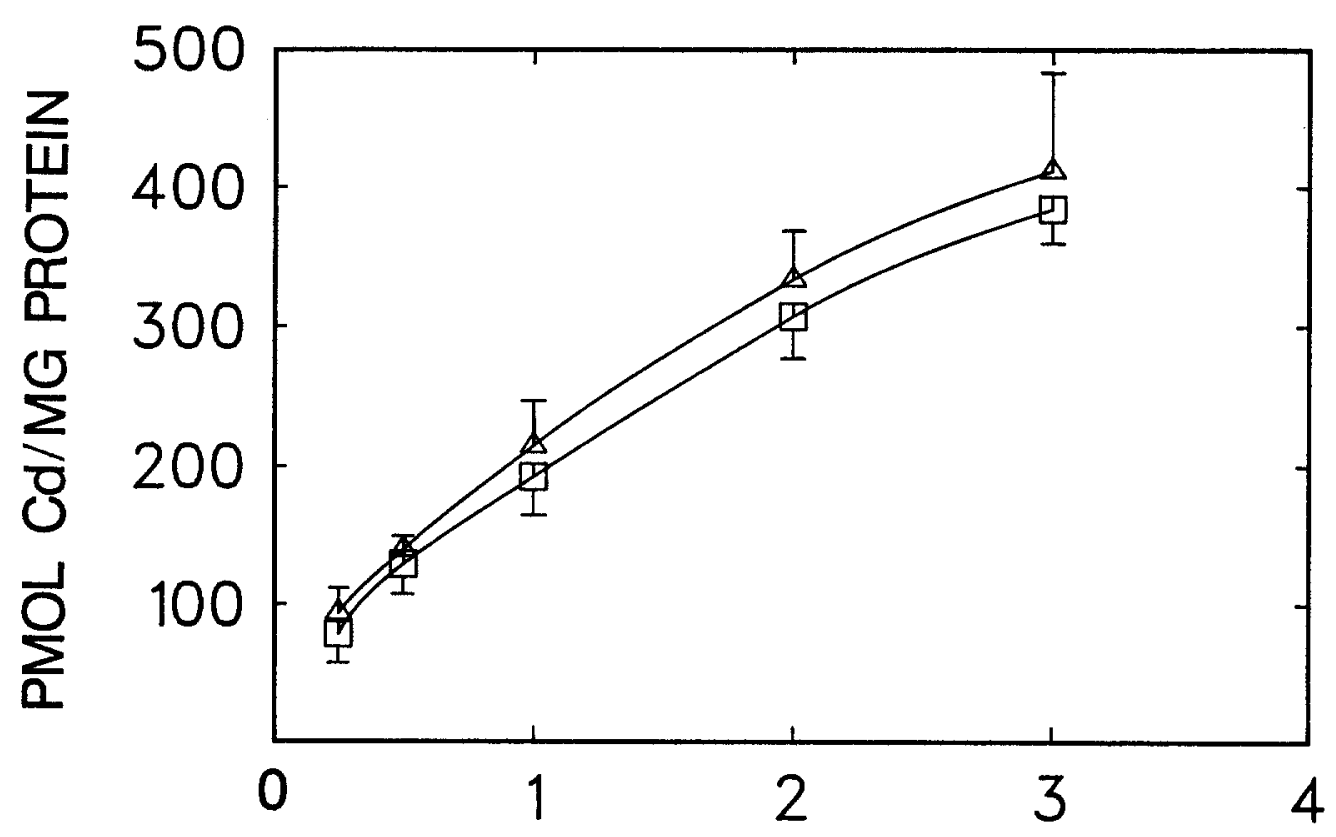

HOURS

FIGURE 1. Uptake of cadmium by Sertoli $(\square)$ and interstitial cell $(\Delta)$ cultures. Cultures $(35 \mathrm{~mm}$ plates) were incubated in media containing $1 \mu \mathrm{M}$ cadmium chloride and $0.2 \mu \mathrm{Ci} \mathrm{Cd}-109$ at $32^{\circ}$ C. At each time point, culture dishes $(\mathrm{N}=3)$ were removed from incubation and washed $2 \times$ with

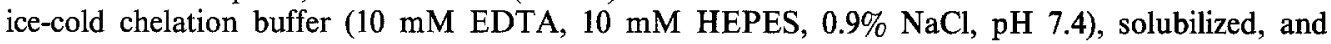
assayed for activity by liquid scintillation spectrometry. Each point represents the mean $(+/-$ range) of two experiments.

normalized per $\mathrm{mg}$ protein, also showed no significant differences between the two types of cells.

Reduction of MTT. Only viable cells with intact mitochondria can reduce the tetrazolium dye MTT, and the amount reduced is directly proportional to the number of viable cells present (Mosmann, 1983), an observation that this laboratory has subsequently confirmed using either protein content or cell number as an endpoint (data not shown).

Figure 2 shows the reduction of MTT as a function of cadmium exposure for both cell types at 12, 24, 48 and 72 hour intervals. Cadmium stimulated formazan production well above that of control for both cell types. However, the maximal response was at a higher cadmium concentration (at all time points) for the ICC than for the SCC. Since both cell types are non-dividing, the increase in formazan production seen most probably reflects an increase in respiratory activity. 


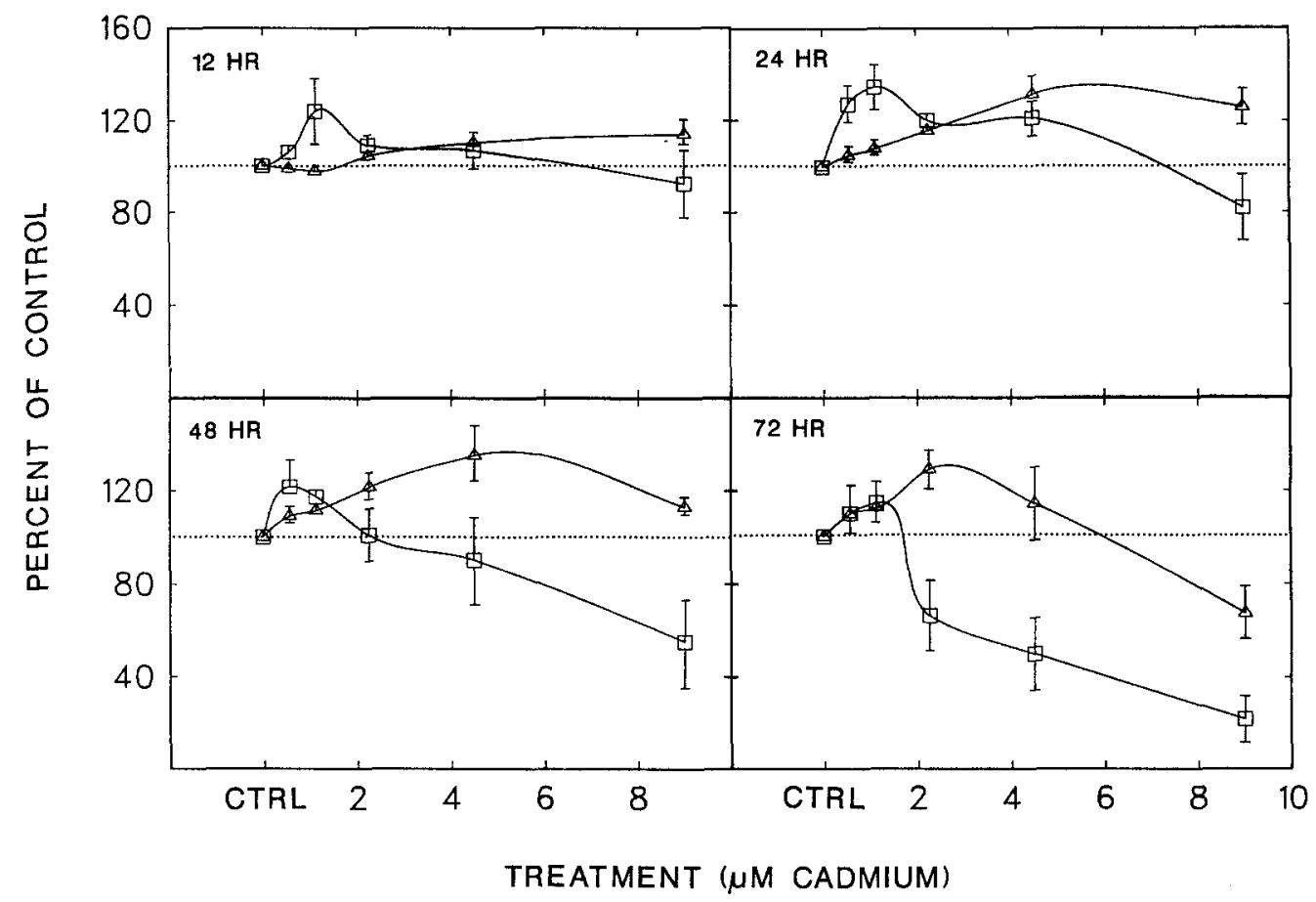

FIGURE 2. Reduction of tetrazolium dye MTT in Sertoli $(\square)$ and interstitital $(\Delta)$ cell cultures, measured over a $72 \mathrm{hr}$ period $\left(32^{\circ} \mathrm{C}\right)$. The horizontal stippled line indicates the control value, normalized as a percentage, for both cell populatios at each time point. Mean $(+/-$ SEM) control values for SCC and ICC were $3.8(0.30)$ and $2.38(0.10) \mu \mathrm{g}$ formazan/well, respectively. Cultures are nondividing, and an increase above control values represents an increase in mitochondrial activity. Each point represents the mean $+/-$ SEM for three experiments ( 4 wells/treatment).

At 48 and 72 hours, concentrations of cadmium $>2.25 \mu \mathrm{M}$ inhibited the reduction of MTT in the SCC (Figure 2). These exposures were accompanied by detachment of dead or dying cells in the SCC. In contrast, the reduction of MTT by ICC was stimulated at all exposures of cadmium tested except at the highest concentration at 72 hours.

When the concentration range for the ICC was extended $(9-64 \mu \mathrm{M})$ and the 72$\mathrm{hr}$ data for both dose response curves (not shown) analyzed by a log-probit method (Litchfield and Wilcoxon, 1949), both plots were linear and parallel. The estimates of the $72 \mathrm{hr} \mathrm{LC}{ }_{50}$ for SCC and ICC were 4.1 and $19.6 \mu \mathrm{M} \mathrm{CdCl}_{2}$, respectively.

Production of Lactate. Cadmium causes a marked increase in lactate production at both 24 and 48 hours in SCC (Figure 3); ICC show a slight but insignificant decrease at the lower dose levels at both time points. The ICC show a significant increase above control $(p<0.01)$ only at 48 hours and at the highest treatment level. 


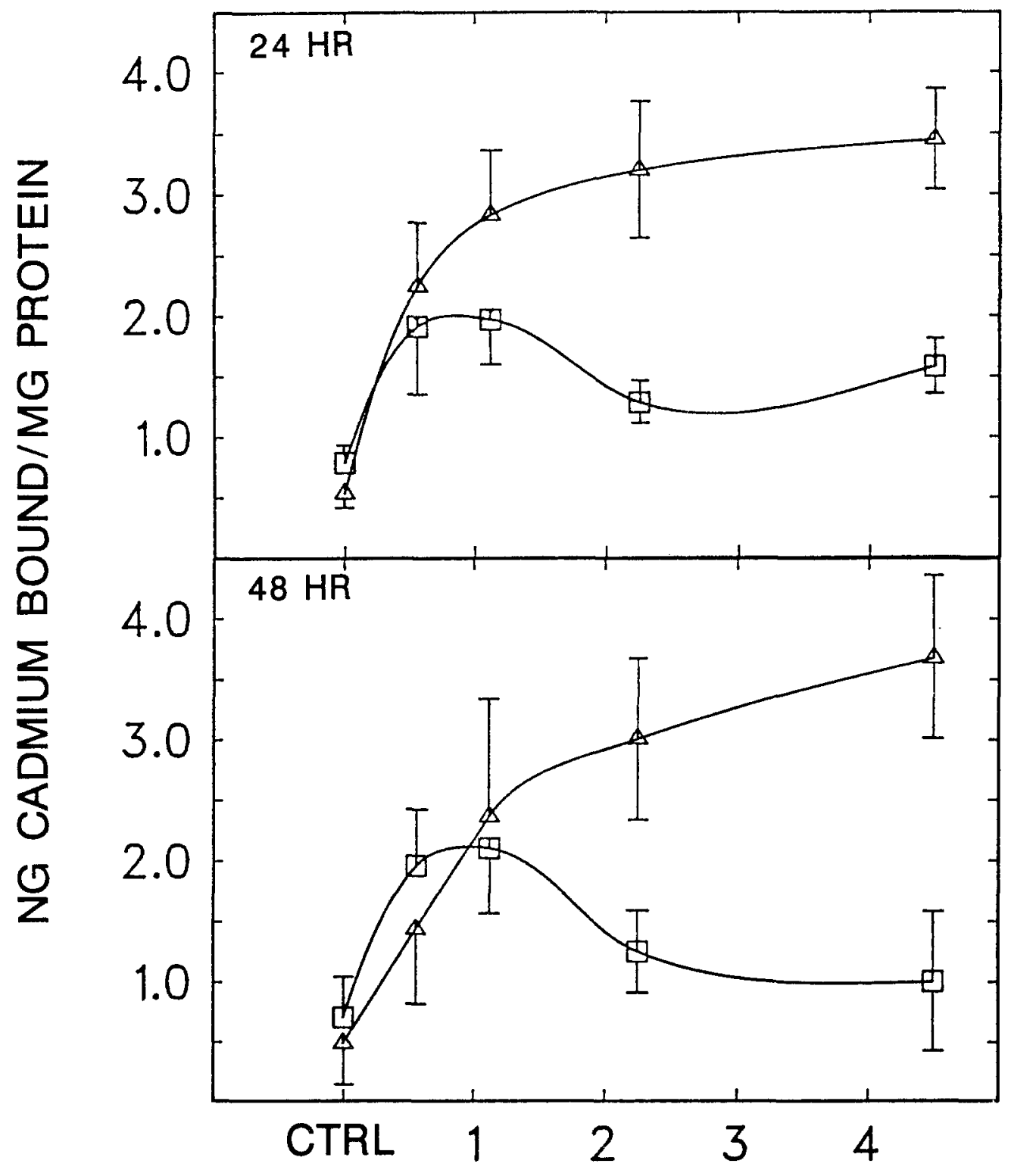

TREATMENT ( $\mu \mathrm{M}$ cadmium)

FIGURE 3. Lactate production by Sertoli $(\square)$ and interstitial $(\Delta)$ cell cultures after incubation at $32^{\circ} \mathrm{C}$ for 24 and $48 \mathrm{hr}$ with increasing concentrations $(0.56-4.5 \mu \mathrm{M})$ of cadmium chloride. Media was removed and lactate concentrations determined enzymatically. Each point represents the mean $+/-$ range of two experiments ( 3 dishes/treatment). 
Protein Synthesis and Induction of Cadmium Binding Capacity. Cadmium effected a dose-dependent decrease in the incorporation of ${ }^{3} \mathrm{H}$-leucine into TCA insoluble protein of the SCC, whereas the ICC were largely unaffected (Figure 4). As can be observed in Figure 5, the production of a heat-stable cadmium binding factor (CBF) was dose-dependent in ICC, whereas SCC exhibited a non-linear doseresponse, most probably due to overt cytotoxicity at the higher cadmium concentrations. SCC are apparently able to maintain production of CBF at concentrations that appreciably inhibit protein synthesis (see Figure 4).

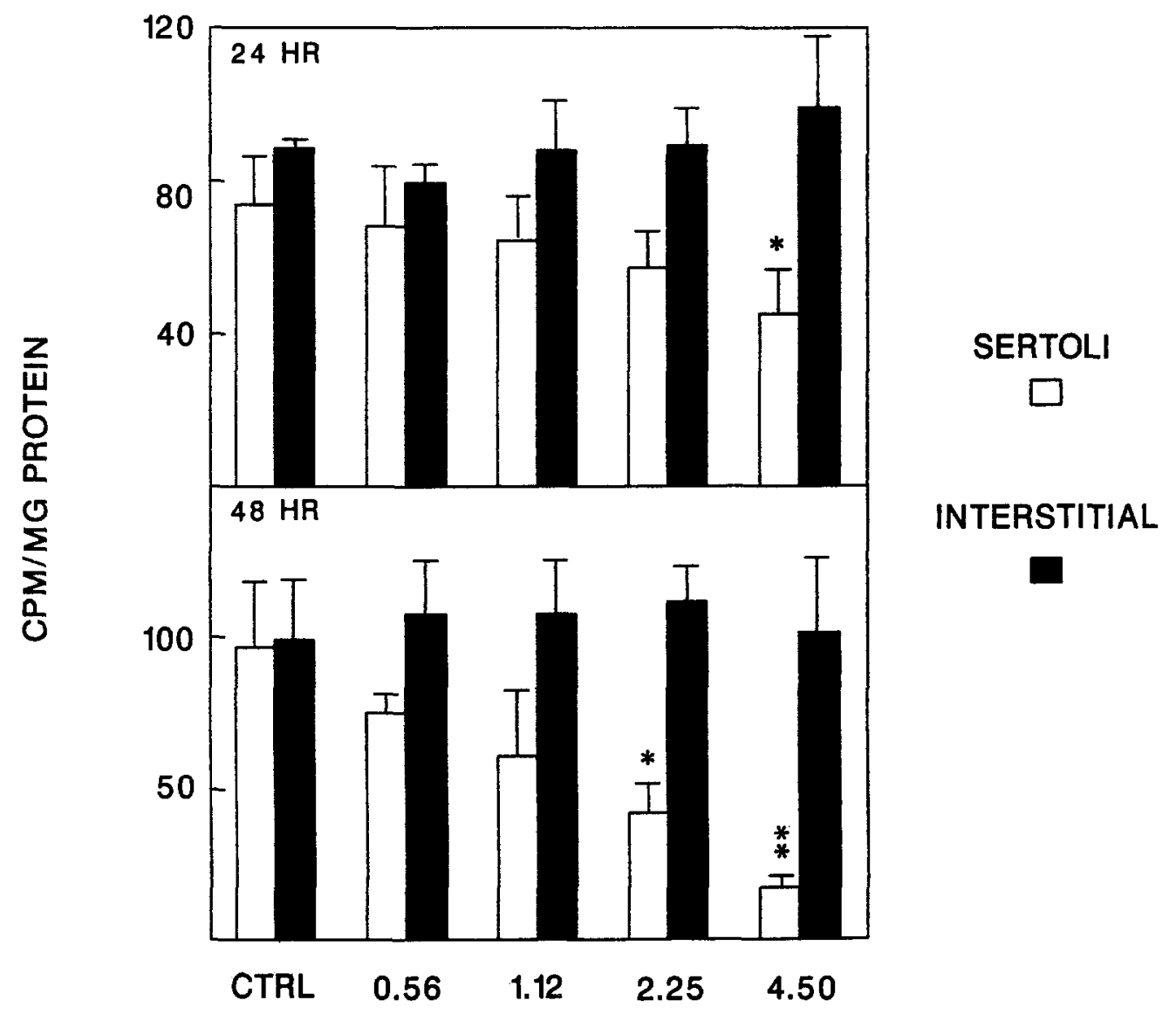

\section{TREATMENT ( $\mu \mathrm{M}$ cadmium)}

FIGURE 4. Protein synthesis, measured by incorporation of ${ }^{3} \mathrm{H}$-leucine, in Sertoli (open) and interstitial (filled) cell cultures after incubation at $32^{\circ} \mathrm{C}$ for 24 and $48 \mathrm{hr}$ with increasing concentrations $(0.56-4.5 \mu \mathrm{M})$ of cadmium chloride. Cycloheximide treated cultures were less than $10 \%$ of control values (data not shown). Each point represents the mean $+/-$ range of two experiments ( 3 dishes/ treatment). 


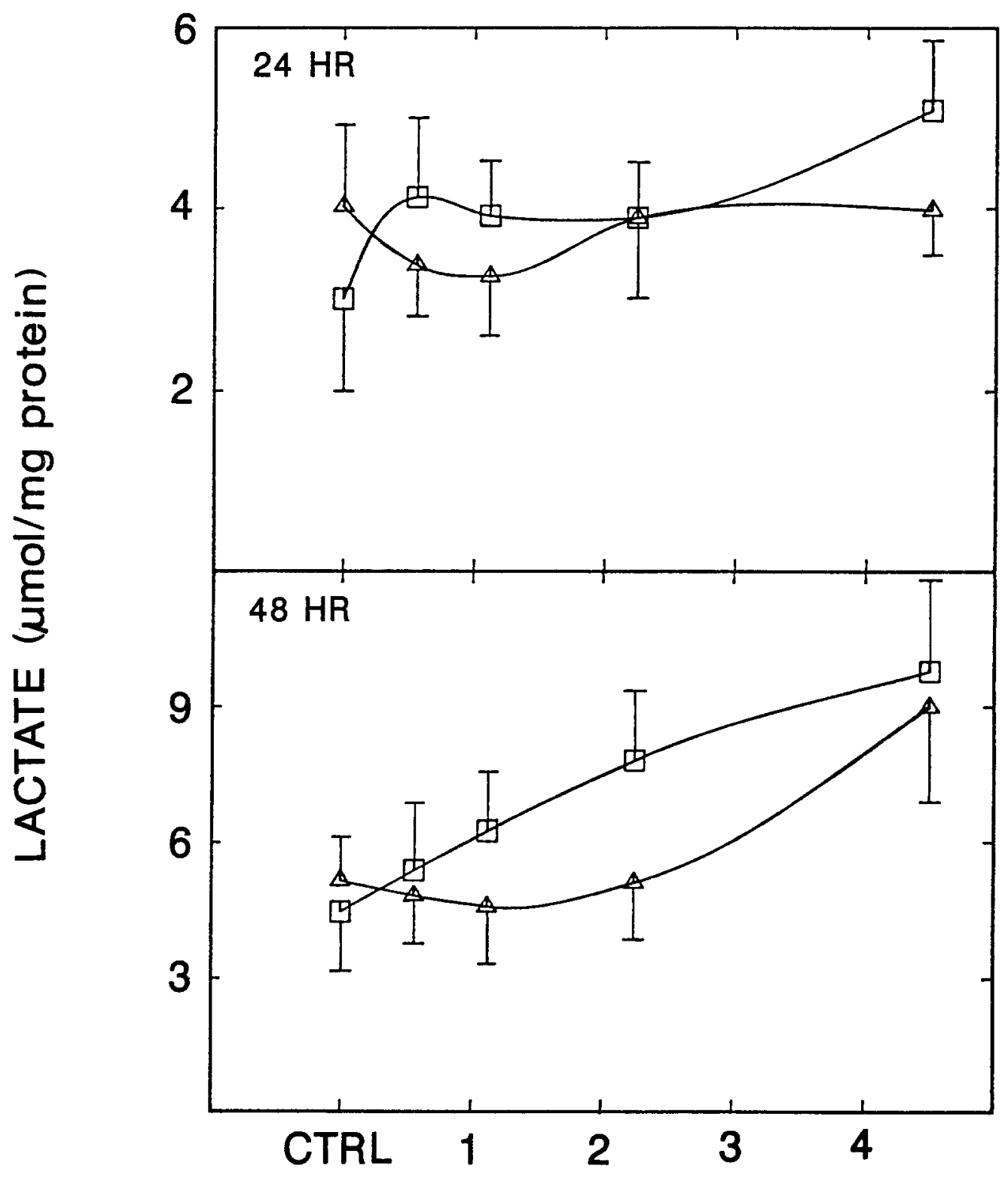

TREATMENT ( $\mu \mathrm{M}$ cadmium)

FIGURE 5. Production of heat-stable cadmium binding factor in Sertoli $(\square)$ and interstitial $(\Delta)$ cell cultures after incubation at $32^{\circ} \mathrm{C}$ for 24 and $48 \mathrm{hr}$ with increasing concentrations $(0.56-4.5$ $\mu \mathrm{M})$ of cadmium chloride. After incubation, the cells were rinsed, frozen and thawed twice in 1 $\mathrm{ml}$ PBS, and sonicated for $1 \mathrm{~min}$. The homogenate was then assayed for protein and 'cadmium binding capacity.' Each point represents the mean $+/-$ range for two experiments ( 3 dishes/treatment). 


\section{DISCUSSION}

The response of two testicular cell types after exposure to cadmium was compared. The design centered around a dual cell culture system that allowed the concomitant isolation, culture, and treatment of primary rat Sertoli and interstitial cells (from a consanguineous source) under identical environmental conditions. Common morphological and biochemical endpoints were selected to compare the response of the two cell cultures to low concentrations of cadmium. With the exception of the high cadmium concentrations for determination of the $\mathrm{LC}_{50}$, all of the endpoints were measured at non-lethal concentrations. The results indicated that the Sertoli cell was markedly more susceptible to the toxic effects of cadmium than the interstitial cell in vitro.

The lowest cadmium concentration required to produce observable changes in Sertoli cell morphology (12-24 hour observation) was approximately $1.2 \mu \mathrm{M} \mathrm{CdCl}_{2}$ (data not shown). The interstitial cells appeared unaffected at concentrations up to 8 $\mu \mathrm{M}$. Once adverse changes had begun, both cell types exhibited similar responses that included cytoplasmic granulation, increased vacuolization, cell contraction and detachment.

The most sensitive endpoint was the reduction of MTT. Because this reagent is reduced by the mitochondrial electron transport chain, an increase in cellular respiration will increase the production of formazan above that of control. This stimulation is apparent in both cell types after exposure to cadmium, as can be clearly seen in Figure 2. This observation is consistent with that of others who have shown that mitochondria will concentrate significant amounts of cadmium in relation to other organelles, and that both the glycolytic and oxidative phosphorylation pathways are affected (Jarvisalo et al., 1980; Toury et al., 1985; Rao, 1983).

The most notable observation to be made with regard to the reduction of MTT by both SCC and ICC is the concentration of $\mathrm{CdCl}_{2}$ required to produce the maximum respiratory stimulation for each cell type. Both maxima differ, by at least a factor of 5 , for the first 48 hours of exposure. Additionally, cell detachment (indicated by formazan concentrations dropping below that of the control group) for the ICC was only observed at the highest concentration $\left(9 \mu \mathrm{M} \mathrm{CdCl}_{2}\right)$ for the longest exposure period $(72 \mathrm{hr}$ ).

Cadmium also inhibited protein synthesis (as measured by ${ }^{3} \mathrm{H}$-leucine incorporation), stimulated lactate production (an indicator of mitochondrial inhibition), and induced cadmium binding capacity in Sertoli cells at concentrations that did not affect the interstitial cells. Cadmium will elicit similar responses in other cell types, albeit at higher concentrations (Muller and Ohnesorge, 1984; Waalkes et al., 1984; DeRuiter et al., 1985; Fischer, 1985; Wade et al., 1986). The uptake of radioactive cadmium revealed that there was no significant difference in the rate of metal transport 
between the two cell types. Thus, the different responses seen in this study cannot be explained by one cell type accumulating more of the metal than the other. Waalkes and Perantoni (1986) reported that the major cadmium binding protein of the testes was distinct from that of liver and kidney in rats and mice. However, the cell population in the testes that is responsible for synthesizing the cadmium binding protein has not been identified. Our data would suggest that the predominant site of synthesis would be the interstitial cell, since this population possessed a higher cadmium binding capacity than the Sertoli cell.

How might these in vitro effects seen in this study be related to the effects seen after administration of low levels of cadmium to the rat in vivo? The Sertoli cells provide structural support for the differentiating germ cells, as well as nourishment (Jutte et al., 1983; Grootegoed, 1988). If cadmium selectively alters Sertoli cell function, as might be suggested by these data, then the seminiferous epithelium would be compromised. The interstitium, however, is anatomically situated to receive the "first pass" of an acute dose and, being less sensitive to the metal, may afford the spermatogenic components some degree of protection. This premise is supported by past studies which have demonstrated that low, non-necrotizing doses $(<4 \mu \mathrm{mol} /$ $\mathrm{kg}$ ) of cadmium will not pass the blood-testis barrier (Gunn et al. 1968b) and that most of the metal absorbed by the testis can be found in the interstitial compartment (Berlin and Ullberg 1963; Gunn et al., 1968b; Danielsson et al., 1984).

As in any in vitro study, extrapolation of the results to the in vivo situation must be made cautiously. The range of cadmium concentrations used in this study were selected by calculating testicular concentrations in the rat after a sub-necrotic exposure in vivo. Assuming 1) and average weight of $1 \mathrm{gram} /$ testis 2) that the testis absorbs $0.1-0.2 \%$ of the cadmium dose (Gunn et al., 1968a) and 3) the density of the testis is one, the calculated range would fall between 1-10 $\mu \mathrm{M}$. However if there is a differential uptake between the interstitium and the seminiferous tubule in vivo, then the exposures in this study may be unrealistically low for ICC and high for SCC.

The resistance to cadmium seen in the interstitial cells might be attributed to using a heterogeneous population of cells. In the present culture system the peritubular and non-specific interstitial cells, as seen in vivo, are closely associated with the Leydig cells, providing a possible means of support, as well as an additional experimental variable not seen in the Sertoli cell cultures. We observed, however, that high concentrations of cadmium selectively destroyed the peritubular and nonspecific interstitial cells, whilst the Leydig cells survived. Further, although both cell types were plated at the same cell density, the Sertoli cell has a relatively larger cell volume than the interstitial cell, and yields slightly more protein per dish, thus providing a confounding variable between the two cell cultures. However, this should afford the Sertoli cells an advantage over that of the interstitial cells, 
since they possess a greater amount of metal buffering capacity (i.e. more protein per cell and per dish) than the latter, especially at the low cadmium concentrations used in this study.

Because the rats used in this study are not fully mature (27-30 day), the relevance to the effects of cadmium on spermatogenesis in the mature animal may be in question. Although not yet fertile, 28 day rats show the typical cellular associations (Perey et al., 1961) up to Stage IX of the seminiferous cycle. Sertoli cells isolated from three week old animals bind FSH, insulin, and IGF-I, and respond with increased rates of lactate synthesis to hormone exposure (Oonk and Grootegoed, 1988). Sertoli cells from three week old rats secrete androgen binding protein, a Sertoli cell marker (Kühn-Velten et al., 1987) and inhibin (Toebosch et al., 1988). It would appear that Sertoli cells from 4 week old rats perform at least qualitatively as well as do cells isolated from older rats. In addition, Wong and Klaassen (1980) have shown that significant effects can be seen in the seminiferous epithelium of cadmium-treated rats as early as 3 weeks of age.

When comparing the response of two cell populations to a toxicant, care must be taken in defining one as "sensitive" or "resistant," since these are relative terms. From the data presented here, it appears that ability of the interstitial cells to tolerate cadmium may be comparable to that seen in studies with primary cells isolated from non-reproductive tissue, e.g. hepatocytes (Muller and Ohnesorge, 1984), kidney cells (Jin and Nordberg, 1986) and white blood cells (Stacey, 1986; Coin and Stevens, 1986). Sertoli cells, on the other hand, appeared to be "sensitive" to the metal, exhibiting even less of a tolerance seen in the more fastidious established cell lines (Fisher, 1985; Borenfreund and Puerner, 1986). Additionally, the logprobit dose-response plots for both cell populations were different by a factor of approximately 5 , although the plots were parallel. Thus, one could argue that the mechanism of toxicity may be similar for both cell types, but that the ICC are better able to sequester cadmium in a manner that favors less interference with vital cellular functions. Since the interstitium lies outside the blood-testis barrier and is situated to receive the initial dose of a potentially toxic metal, it is logical that this population be inherently more "resistant" to toxic insult.

In summary, we have shown, using common biochemical endpoints, that Sertoli cells are significantly more sensitive to the effects of cadmium than partially purified interstitial cells. The dichotomous response seen in both cell populations may cast a different perspective on the toxicity of heavy metals in the testis. Specifically, the most susceptible cell population in an organ may account for the susceptibility of the organ (to a toxicant) as a whole. In addition, the in vitro dual cell model we have developed and employed in this study reduced animal use and served as a cost-effective tool in the investigation of the reproductive toxicity of cadmium. It shows potential for elucidating some of the early biochemical alterations that 
this metal may induce in the cell. The model may also be helpful in the investigation of the mechanism of other xenobiotics that may be potentially harmful to the testis.

\section{REFERENCES}

BEATTIE, P. J., WELSH, M. J., and BRABEC, M. J. (1984). The effect of 2methoxyethanol and methoxyacetic acid on Sertoli cell lactate production and protein synthesis in vitro. Toxicol. Appl. Pharmacol. 76:56-61.

BERLIN, M. and ULLBERG, S. (1963). The fate of Cd-109 in the mouse. Arch. Envir. Health 7:686-693.

BRABEC, M. J., BEDOWS, E., DAVIDSON, B. and KNIGHT, P. R. (1984). Effect of general anesthetics and pressure on aerobic metabolism of monkey kidney cells. Anesthesiology 61:43-48.

BORENFREUND, E. and PUERNER, J. A. (1986). Cytotoxicity of metals, metal-metal and metal-chelator combinations assayed in vitro. Toxicology 39:121-134.

BOSCOLO, P., SACCHETTONI-LOGROSCINO, G., RANELLETTI, F. O., GIOIA, A., and CARMIGNANI, M. (1985). Effects of long-term cadmium exposure on the testis of rabbits: Ultrastructural study. Toxicol. Lett. 24:145-149.

CHASE, D. J. and PAYNE, A. H. (1983). Changes in distribution and androgen production of Leydig cells of two populations during sexual maturation in the rat. Endocrinology 112:29-34.

CHUNG, A. S. and MAINES, M. D. (1987). Differential effect of cadmium on GSHperoxidase activity in the Leydig and the Sertoli cells of rat testes. Biochem. Pharmacol. 36:1367-1372.

COIN, P. G. and STEVENS, J. B. (1986). Toxicity of cadmium chloride in vitro: Indices of cytotoxicity with the pulmonary alveolar macrophage. Toxicol. Appl. Pharmacol. 82:140-150.

DANIELSSON, B. R. G., DENCKER, L., LINDGREN, A. and TJÄLVE, H. (1984). Accumulation of toxic metals in male reproductive organs. Arch. Toxic. Suppl. 7:177-180.

DE RUITER, N., MAILÄNDER, V., and KAPPUS, H. (1985). Effect of heavy metals on cellular growth, metabolism, and integrity of Chinese hamster kidney cells. Xenobiotica 15:665-671.

EATON, D. L. and TOAL, B. F. (1982). Evaluation of the Cd/Hemoglobin affinity assay for the rapid determination of metallothionein in biological tissues. Toxic. Appl. Pharmacol. 66:134-142.

ESPEVIK, T., LAMVIK, M. K., SUNDE, A. and EIK-NES, K. B. (1982). Effect of cadmium on survival and morphology of cultured rat Sertoli cells. J. Reprod. Fert. 65:489-495.

FAILLA, M. L. and COUSINS, R. J. (1978). Zinc uptake by isolated rat liver parenchymal cells. Biochem. Biophys. Acta. -538:435-444.

FISCHER, A. B. (1985). Factors influencing cadmium uptake and cytotoxicity in cultured cells. Xenobiotica 15:751-757.

GAD, S. C. and WEIL, C. S. (1982). "Statistics for Toxicologists" in Principles and Methods of Toxicology. (A. Wallace Hayes, ed.) Raven Press, New York, NY.

GALDIERI, M., ZIPARO, E., FIORETTA, P., RUSSO, M. A. and STEFANINI, M. (1981). Pure Sertoli cell cultures: A new model for the study of somatic-germ cell interactions. J. Androl. 5:249-254. 
GROOTEGOED, J. A. (1988). Towards a better understanding of Sertoli cell function. Int. J. Androl. 10:727-729.

GUNN, S. A., GOULD, T. C. and ANDERSON, W. A. D. (1966). Protective effect of thiol compounds against cadmium-induced vascular damage to testis. Proc. Soc. Exp. Biol. Med. 122:1036-1039.

GUNN, S. A., GOULD, T. C. and ANDERSON, W. A. D. (1968a). Selectivity of organ response to cadmium injury and various protective measures. J. Path. Bact. 96:89-96.

GUNN, S. A., GOULD, T. A. and ANDERSON, W. A. D. (1968b). Failure of ${ }^{109} \mathrm{Cd}$ to traverse spermatogenic pathway. J. Reprod. Fert. 16:125-128.

HOHORST, H. J. (1965). L-(+)-Lactate: Determination with lactic dehydrogenase and DPN. In: Methods of Enzymatic Analysis (H. U. Bergmeyer, ed.), pp. 266-270. Verlag Chemie, Weinheim.

JARVISÄLO, J. O., KILPIÖ, J. and SARIS, N. L. (1980). Toxicity of cadmium to renal mitochondria when administered in vivo and in vitro. Envir. Res. 22:217-223.

JIN, T. and NORDBERG, G. F. (1986). Cadmium toxicity in kidney cells. Resistance induced by short term pretreatment in vitro and in vivo. Acta Pharm. Toxic. 58:137-143.

JUTTE, N. H. P. M., JANSEN, R., GROOTEGOED, J. A., ROMMERTS, F. F. G. and VAN DER MOLEN, H. J. (1983). FSH stimulation of the production of pyruvate and lactate by rat Sertoli cells may be involved in hormonal regulation of spermatogenesis. J. Reprod. Fertil. 68:219-226.

KAR, A. B., and DAS, R. P. (1960). Testicular changes in rats after treatment with cadmium chloride. Acta Biol. Med. Ger. 5:153-173.

K ̈̈HN-VELTEN, N., BOS, D., SCHERMER, R. and STAIB, W. (1987). Age-dependence of the rat Leydig cell and Sertoli cell function. Development of the peripheral testosterone level and its relation to mitochondrial and microsomal cytochromes P-450 and to androgen-binding protein. Acta Endocrin. 115:275-281.

LASKEY, J. W., REHNBERG, G. L., LAWS, S. C. and HEIN, J. F. (1984). Reproductive effects of low acute doses of cadmium chloride in adult male rats. Toxicol. Appl. Pharmacol. 73:250-255.

LASKEY, J. W., REHNBERG, G. L., LAWS, S. C. and HEIN, J. F. (1986). Age-related dose-response of selected reproductive parameters to acute cadmium chloride exposure in the male Long-Evans rat. J. Toxicol. Environ. Health 19:393-401.

LEE, I. P., and DIXON, R. L. (1973). Effects of cadmium on spermatogenesis studied by velocity sedimentation cell separation and serial mating. J. Pharmacol. Exp. Ther. 187:641-652.

LEE, I. P. (1983) In: Reproductive and Developmental Toxicity of Metals. (Clarkson, C. W., Nordberg, G. F., and Seger, P. W., eds.) Plenum Press, New York and London.

LITCHFIELD, J. T., and WILCOXON, F. (1949). A simplified method of evaluating dose-effect experiments. J. Pharmacol. Exper. Ther. 96:99-113.

LOWRY, O. H., ROSEBROUGH, N., FARR, A. and RANDALL, R. (1951). Protein measurement with the Folin phenol reagent. J. Biol. Chem. 193:265-275.

MATHER, J. P. (1980). Establishment and characterization of two distinct mouse testicular epithelial cell lines. Biol. Reprod. 23:243-252.

MEEK, E. S. (1959). Cellular changes induced by cadmium in mouse testis and liver. Brit. J. Exp. Pathol. 40:503-507.

MOSMANN, T. (1983). Rapid colorimetric assay for cellular growth and survival: Application to proliferation and cytotoxicity assays. J. Immun. Meth. 65:55-63. 
MÜLLER, L. and OHNESORGE, F. K. (1984). Cadmium-induced alteration of the energy level in isolated hepatocytes. Toxicology 31:297-306.

ONSAKA, S., KEIICHI, T., DOI, M. and KUNIO, O. (1978). A simplified procedure for determination of metallothionein in animal tissues. Eisei Kagaku 24(3):128-131.

OONK, R. B. and GROOTEGOED, J. A. (1988). Insulin-like growth factor I (IGF-I) receptors on Sertoli cells from immature rats and age-dependent testicular binding of IGF-I and insulin. Molec. Cell. Endocrin. 55:33-43.

PARIZÉK, J. (1983). In: Reproductive and Developmental Toxicity of Metals. (Clarkson, C. W., Nordberg, G. F. and Seger, P. W., eds.). Plenum Press, New York and London.

PARIZÉK, J. and ZAHOR, Z. (1956). Effect of cadmium salts on testicular tissue. Nature (London) 177:1036.

PEARSE, A. G. E. (1960). In: Histochemistry, Theoretical and Applied. 2nd ed. Boston, Little, Brown.

PEREY, B., CLERMONT, Y., and LEBLOND, C. P. (1961). The wave of the seminiferous epithelium in the rat. Am. J. Anat. 108:47-77.

PETERSON, G. L. (1977). A simplification of the protein assay method of Lowry et al. which is more generally applicable. Anal. Biochem. 83:346-356.

RAO, PRASADA P. V. V. (1983). Effects of intraperitoneal cadmium administration on mitochondrial enzymes in rat tissues. Toxicology 27:81-87.

SINGHAL, R. L., VIJAYVARGIYA, R., and SHUKLA, G. S. (1985). Toxic effects of cadmium and lead on reproductive functions. In: Endocrine Toxicology (J. A. Thomas, ed.). Raven Press, New York.

STACEY, N. H. (1986). Effects of cadmium and zinc on spontaneous and antibodydependent cell-mediated cytotoxicity. J. Toxicol. Env. Health. 18:293-300.

TASH, J. S., WELSH, M. J. and MEANS, A. R. (1981). Regulation of protein kinase inhibitor by follicle-stimulating hormone in Sertoli cells in vitro. Endocrinology 108:427-434.

TOEBOSCH, A. M. W., ROBERTSON, D. M., TRAPMAN, J., KLAASSEN, P., DE PAUS, R. A., DE JONG, F. H. and GROOTEGOED, J. A. (1988). Effects of FSH and IGF-I on immature rat Sertoli cells: inhibin $\alpha$ - and $\beta$-subunit mRNA levels and inhibin secretion. Molec. Cell. Endocrin. 55:101-105.

TOURY, R., STELLY N., BOISSONNEAU, E. and DUPUIS, Y. (1985). Degenerative processes in skeletal muscle of $\mathrm{Cd}^{+2}$-treated rats and $\mathrm{Cd}^{+2}$ inhibition of mitochondrial $\mathrm{Ca}^{+}{ }^{2}$ transport. Toxicol. Appl. Pharmacol. 77:19-35.

WAALKES, M. P., POISNER, A. M., WOOD, G. W. and KLAASSEN, C. D. (1984). Metallothionein-like proteins in human placenta and fetal membranes. Toxicol. Appl. Pharmacol. 74:179-184.

WAALKES, M. P. and PERANTONI, A. (1986). Isolation of a novel metal-binding protein from rat testes. J. Biol. Chem. 261:13097-13103.

WAAlKeS, M. P., PERANTONI, A., BHAVE, M. R. and REHM, S. (1988). Strain dependence in mice of resistance and susceptibility to the testicular effects of cadmium: Assessment of the role of testicular cadmium-binding proteins. Toxicol. Appl. Pharmacol. 93:47-61.

WAALKES, M. P. and POIRIER, L. A. (1985). Interactions of cadmium with interstitial tissue of the rat testes. Uptake of cadmium by isolated interstitial cells. Biochem. Pharmaco. 34:2513-2518.

WADE, J. V., AGRAWAL, P. R. and POISNER, A. M. (1986). Induction of metallothionein in a human trophoblast cell line by cadmium and zinc. Life Sci. 39:1361-1366. 
WELSH, M. J. and WIEBE, J. P. (1975). Rat Sertoli cells: A rapid method for obtaining viable cells. Endocrinology 96:618-624.

WONG, K. L. and KLAASSEN, C. D. (1980). Age difference in the susceptibility to cadmium-induced testicular damage in rats. Toxicol. Appl. Pharmacol. 93:456-466. 